\title{
Analisis Kondisi Lingkungan Kerja dalam Meningkatkan Employee Engagement pada Karyawan Bagian Produksi Industri Manufaktur di Cimahi
}

\author{
R. Gunawan, S. H. Senen, \& E. Tarmedi \\ Universitas Pendidikan Indonesia \\ rikigunawan@student.upi.edu
}

\begin{abstract}
Employee engagement is one of the main issues in human resources management and organizations, because it is considered as a major factor in measuring the strength of a company. Issues regarding employee engagement occur in various industries, including manufacturing. It's like what happened to PT. Pola Manunggal Sejati Cimahi, low indicator of employee engagement can be seen from high employee turnover, increased absence, and production targets that have decreased every year, so that the resulting production especially in the year 2016-2018 did not achieve the targets set by the company. This research uses descriptive and verification method, with explanatory survey method. The sampling technique used is probability sampling using the simple random sampling which amounted to 81 people. Data analysis technique used is simple linear regression with program tools SPSS (Statistical Product for Service Solution) 25.0 for Windows. The results of this study indicate that the description of the work environment in good category, description of the employee engagement in high category, and the employee engagement is affected by the work environment. So that the work environment should be considered in support of improving employee engagement.
\end{abstract}

\section{Keywords: Work Environment, Employee Engagement.}

Abstrak: Employee engagement merupakan salah satu isu utama permasalahan dalam manajemen sumber daya manusia dan organisasi, karena merupakan hal yang diperhitungkan sebagai faktor utama dalam mengukur kekuatan sebuah perusahaan. Permasalahan mengenai employee engagement terjadi pada berbagi industri, termasuk industri manufaktur. Hal ini seperti yang terjadi pada PT. Pola Manunggal Sejati Cimahi, dimana indikator rendahnya tingkat employee engagement bisa dilihat dari turnover karyawan yang tinggi, ketidakhadiran yang meningkat, dan target produksi yang mengalami penurunan setiap tahunnya, sehingga produksi yang dihasilkan terutama di tahun 2016-2018 tidak mencapai target yang telah ditetapkan oleh perusahaan. Penelitian ini menggunakan metode deskriptif dan verifikatif, dengan metode explanatory survey. Adapun teknik penarikan sampel yang digunakan yaitu probability sampling dengan menggunakan simple random sampling pada karyawan yang berjumlah 81 orang. Teknik analisis data yang digunakan adalah regresi linear sederhana dengan alat bantu program SPSS (Statistical Product for Service Solution) 25.0 for Windows. Hasil penelitian ini menunjukkan bahwa gambaran lingkungan kerja dalam kategori baik, gambaran employee engagement dalam kategori tinggi, dan employee engagement dipengaruhi oleh lingkungan kerja. Sehingga lingkungan kerja perlu diperhatikan dalam menunjang peningkatan employee engagement.

Kata kunci : Lingkungan Kerja, Employee Engagement.

\section{PENDAHULUAN}

Employee engagement merupakan salah satu isu utama permasalahan dalam manajemen sumber daya manusia dan organisasi (Saks, 2006). Karyawan yang kurang memiliki rasa engaged akan menunjukkan berbagai perilaku yang kurang produktif dan menghambat usaha tim yang sinergis menuju tujuan organisasi, yang akhirnya akan berdampak ke menurunnya kinerja karyawan di bawah 
standar diantara karyawan yang lainnya (Koti \& Road, 2015).

Oleh sebab itu, employee engagement ini perlu menjadi salah satu perhatian utama bagi organisasi karena employee engagement dipertimbangkan sebagai masalah serius bagi banyak organisasi, fenomena ini dianggap sebagai masalah tetap bagi sebuah organisasi saat ini (Nazir \& Jamid, 2017).

Employee engagement lebih dari inisiatif sumber daya manusia dan merupakan dorongan untuk mengendalikan kinerja serta pondasi stratejik yang bisa mengarah pada tujuan organisasi (Sumadhinata \& Murtisari, 2017). Untuk dapat mencapai tujuan perusahaan secara lebih optimal, karyawan perlu merasa memiliki engagement yang kuat dengan tujuan dan identitas perusahaan itu sendiri (Nazir \& Jamid, 2017). Karyawan akan merasa engaged ketika mereka menemukan motivasi dan makna pribadi dalam pekerjaan mereka serta mendapatkan dukungan yang positif serta beroperasi dalam lingkungan kerja yang efisien (Pan \& Degre, 2015).

Organisasi harus menyadari pentingnya membuat karyawan merasa engaged tehadap organisasi serta membuat karyawan menjadi bergairah tentang pekerjaan yang mereka jalankan (Josephine \& Virginia, 2013:111). Kemampuan organisasi untuk mengelola employee engagement yang berkaitan erat dengan kemampuan karyawan untuk mencapai tingkat kinerja yang tinggi (Mishra \& Kumar, 2016:349). Oleh sebab itu, employee engagement merupakan hal yang diperhitungkan sebagai faktor utama dalam mengukur kekuatan sebuah perusahaan atau company's vigor (Johanim et al., 2013).

Indikator rendahnya employee engagement dapat dilihat dari menurunnya produktivitas, menurunnya keuntungan perusahaan, kualitas kerja yang rendah, menurunnya efisiensi kerja, turnover yang tinggi, serta meningkatnya ketidakhadiran karyawan (Handoko, 2014:124).
Fenomena rendahnya employee engagement juga terjadi pada PT. Pola Manunggal Sejati Cimahi yang bergerak dibidang industri manufaktur, terletak di Jl. Pahlawan Desa No. 132 Margaasih Cimahi 40533. Perusahaan masih mengalami beberapa masalah yang berhubungan dengan employee engagement khususnya pada bagian produksi yang merupakan salah satu bagian penting dalam perusahaan.

Pertama, pada tahun 2018 banyak pegawai yang mengajukan pengunduran diri, dikarenakan beban kerja yang berat dan juga keinginan untuk bekerja di perusahaan lain sehingga pada tahun 2018 banyak penerimaan pegawai baru. Kedua, masih terdapat pegawai yang tidak disipilin bekerja pada saat jam kerja. Ketiga, tidak tercapainya target produksi yang telah direncanakan sebelumnya. Berbagai permasalahan tersebut dapat mengurangi efisiensi dan produktivitas serta mengancam kelangsungan hidup jangka panjang perusahaan.

Salah satu indikator rendahnya employee engagement yaitu turnover karyawan, hal ini sesuai dengan teori yang dikemukakan oleh Koti \& Road (2015) yang menyatakan bahwa karyawan yang tidak engaged cenderung untuk meninggalkan pekerjaan mereka, jika seseorang tidak memiliki komitmen emosional untuk pekerjaan mereka, ada kemungkinan besar bahwa mereka akan meninggalkan dan mengejar pekerjaan yang lebih baik.

Tingkat turnover karyawan bagian produksi PT. Pola Manunggal Sejati Cimahi telah melebihi standar yang ditolerir yaitu sebesar $10 \%$ per tahun. Standar tingkat turnover karyawan yang bisa ditolerir pada setiap perusahaan berbeda-beda, namun jika tingkat turnover mencapai lebih dari $10 \%$ per tahun maka terlalu tinggi menurut banyak standar (Sujeewa, 2011).

Ketika karyawan meninggalkan perusahaan biasanya melibatkan biaya perekrutan, pelatihan, upah seorang 
karyawan pemula, serta hilangnya produksi selama selang waktu antara pemutusan hubungan kerja dengan karyawan lama dan pergantian oleh karyawan baru, akan mengakibatkan kesulitan dalam memenuhi target produksi perusahaan jika tingkat turnover terlalu tinggi. Fenomena di atas menunjukkan adanya kecenderungan pegawai tidak engaged terhadap perusahaan dengan adanya penurunan jumlah karyawan dan tingkat turnover yang tinggi.

Sementara itu, rekapitulasi ketidakhadiran karyawan dapat dijadikan sebagai indikator penunjang dalam penilaian tingkat employee engagement, hal ini sesuai dengan teori yang dikemukakan oleh Handoko (2014:124) yang menyatakan bahwa meningkatnya ketidakhadiran menjadi salah satu ciri karyawan yang tidak engaged, persentase ketidakhadiran dapat mencerminkan tinggi atau rendahnya disiplin kerja seorang karyawan dalam menjalankan tugasnya.

Pada tahun 2016 ketidakhadiran karyawan yaitu sebesar 503 orang, kemudian di tahun 2017 mengalami peningkatan menjadi 534 orang, selanjutnya di tahun 2018 mengalami peningkatan kembali yang sangat tinggi yaitu sebesar 562 orang. Apabila hal ini terus terjadi maka akan menghambat terhadap proses kegiatan produksi, sehingga berdampak pula terhadap produktivitas perusahaan. Hasil jumlah ketidakhadiran karyawan ini dapat menjadi tolok ukur, bahwa semakin tinggi tingkat ketidakhadiran karyawan, maka semakin rendah tingkat engaged terhadap perusahaan yang dirasakan oleh karyawan. Indikator lain dari rendahnya employee engagement yaitu menurunnya produktivitas karyawan, hal ini sesuai dengan teori yang dikemukakan oleh Al-Tit \& Hunitie (2015) yang menyatakan bahwa rendahnya employee engagement yang tidak diatasi dapat berdampak terhadap hasil organisasi seperti kinerja karyawan yang menurun dan tidak tercapainya target perusahaan.

setiap tahun realisasi produksi kain polyester tidak dapat mencapai target yang telah ditetapkan oleh perusahaan dan selalu mengalami penurunan. Pada tahun $2016 \mathrm{ke}$ 2017 mengalami penurunan jumlah produksi dengan selisih $374.315 \mathrm{yd}$, dari 9.121.015 yd menjadi 8.746.700 yd. Pada tahun 2017 ke 2018 mengalami penurunan jumlah produksi dengan selisih $328.659 \mathrm{yd}$, dari 8.746.700 yd menjadi 8.418.041 yd.

Realisasi produksi kain polyester setiap tahunnya tidak mencapai target produksi yang telah ditetapkan yaitu 10.000.000 yd. Hal ini disebabkan karena karyawan kurang memiliki rasa engaged yang akhirnya berdampak terhadap kurangnya etos kerja yang baik dalam menjalankan tugas-tugas yang dikerjakannya, serta kurangnya disiplin kerja dalam mematuhi aturan yang ditetapkan oleh perusahaan. Jika penurunan produksi tidak segera diatasi maka perusahaan akan mengalami kerugian yang cukup besar, karena hasil yang didapat tidak sesuai dengan biaya yang dikeluarkan.

TABEL 1.

TURNOVER KARYAWAN BAGIAN PRODUKSI PT. POLA MANUNGGAL SEJATI CIMAHI TAHUN 2016-2018

\begin{tabular}{cccccc}
\hline Tahun & $\begin{array}{c}\text { Jumlah Awal } \\
\text { Karyawan }\end{array}$ & $\begin{array}{c}\text { Karyawan } \\
\text { Masuk }\end{array}$ & $\begin{array}{c}\text { Karyawan } \\
\text { Keluar }\end{array}$ & $\begin{array}{c}\text { Jumlah } \\
\text { Karyawan }\end{array}$ & Persentase \\
\hline 2016 & 426 & 46 & 53 & 430 & $12,38 \%$ \\
2017 & 430 & 48 & 65 & 413 & $15,42 \%$ \\
2018 & 413 & 51 & 62 & 402 & $15,21 \%$ \\
\hline
\end{tabular}

Sumber: Bagian HRD PT. Pola Manunggal Sejati Cimahi 
TABEL 2.

REKAPITULASI KETIDAKHADIRAN KARYAWAN BAGIAN PRODUKSI PT.
POLA MANUNGGAL SEJATI CIMAHI TAHUN 2016-2018

Sumber: Bagian HRD PT. Pola Manunggal Sejati Cimahi

TABEL 3.

TARGET PRODUKSI PT. POLA MANUNGGAL SEJATI CIMAHI TAHUN 20162018

\begin{tabular}{cccc}
\hline Tahun & $\begin{array}{c}\text { Target } \\
\text { Perusahaan (yd) }\end{array}$ & Realisasi (yd) & $\begin{array}{c}\text { Persentase } \\
\text { Terealisasi }\end{array}$ \\
\hline 2016 & 10.000 .000 & 9.121 .015 & $91 \%$ \\
2017 & 10.000 .000 & 8.746 .700 & $87 \%$ \\
2018 & 10.000 .000 & 8.418 .041 & $84 \%$ \\
\hline
\end{tabular}

Sumber: Bagian HRD PT. Pola Manunggal Sejati Cimahi

Lingkungan kerja merupakan faktor yang digunakan untuk menyelesaikan permasalahan employee engagement pada penelitian kali ini, karena terdapat beberapa literatur yang menyatakan bahwa lingkungan kerja merupakan bagian dari faktor yang dapat mendorong peningkatan employee engagement (Lockwood, 2007).

Secara garis besar, jenis lingkungan kerja terbagi menjadi dua yaitu lingkungan kerja fisik dan lingkungan kerja sosial. lingkungan kerja fisik meliputi semua keadaan berbentuk fisik yang terdapat di sekitar tempat kerja yang dapat mempengaruhi karyawan baik secara langsung maupun secara tidak langsung. Sedangkan lingkungan kerja sosial meliputi semua keadaan yang terjadi yang berkaitan dengan hubungan kerja, baik hubungan dengan atasan maupun hubungan sesama rekan kerja, ataupun hubungan dengan bawahan (Sedarmayanti, 2014:26).

Lingkungan kerja menjadi salah satu faktor yang dapat mempengaruhi employee engagement, pemerhatian terhadap sistem kerja, desain kerja, kondisi kerja, dan cara-cara di mana karyawan diperlakukan di tempat kerja dapat mempengaruhi kondisi fisik dan psikologi karyawan baik secara langsung maupun tidak langsung yang nantinya akan meningkatkan engaged karyawan terhadap perusahaan (Armstrong \& Taylor, 2017).

Employee engagement dalam suatu organisasi sangat dipengaruhi oleh kondisi lingkungan tempat mereka bekerja, karena 
keadaan lingkungan kerja yang kurang baik dapat menuntut tenaga dan waktu yang lebih banyak, yang tentunya tidak mendukung diperolehnya rancangan sistem kerja yang efisien dan produktif. Oleh sebab itu, pemerhatian terhadap kondisi lingkungan di suatu organisasi merupakan hal yang harus diutamakan untuk menunjang keberhasilan pencapaian tujuan (Idaya et al., 2016).

Dalam membentuk sikap employee engagement terdapat tiga faktor yang harus diperhatikan perusahaan yaitu organisasi, manajemen dan kepemimpinan, dan lingkungan kerja. Hal ini karena jika organisasi tempat karyawan bekerja membantu karyawan untuk berkembang, manajemen dan kepemimpinan dapat membantuk karyawan menyelesaikan permasalahan pekerjaan, dan kondisi lingkungan kerja mendukung karyawan memberikan kinerja terbaik, maka tingkat engaged karyawan terhadap perusahaan akan meningkat serta karyawan memiliki motivasi tinggi untuk memberikan kinerja terbaik (McBain, 2007).

Rumusan masalah dalam penelitian ini adalah bagaimana gambaran lingkungan kerja di PT. Pola Manunggal Sejati Cimahi, gambaran employee engagement di PT. Pola Manunggal Sejati Cimahi, dan seberapa besar pengaruh lingkungan kerja dalam meningkatkan employee engagement pada PT. Pola Manunggal Sejati Cimahi. Paradigma penelitian dapat dilihat pada Gambar 1. mengenai Paradigma Penelitian Pengaruh Lingkungan Kerja terhadap Employee Engagement berikut:

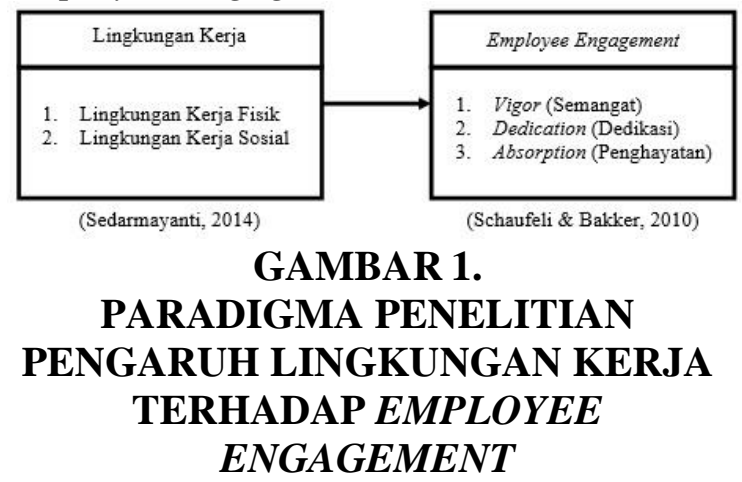

Hipotesis penelitian sebagai berikut: "Terdapat pengaruh lingkungan kerja terhadap employee engagement."

\section{METODE PENELITIAN}

Pendekatan yang digunakan dalam penelitian ini yaitu pendekatan manajemen sumber daya manusia, khususnya mengenai pengaruh lingkungan kerja terhadap employee engagement pada karyawan bagian produksi PT. Pola Manunggal Sejati di Cimahi. Dalam penelitian ini terdapat dua variabel, yaitu variabel independen dan variabel dependen. Variabel independen pada penelitian ini adalah lingkungan kerja (X) yang terdiri dari dimensi 1) lingkungan kerja fisik dan 2) lingkungan kerja sosial. Variabel dependen pada penelitian ini adalah employee engagement (Y) yang terdiri dari dimensi 1) vigor (semangat), 2) dedication (dedikasi), dan 3) absorption (penghayatan).

Unit analisis dalam penelitian ini adalah karyawan bagian produksi PT. Pola Manunggal Sejati Cimahi, yang berlokasi di Jl. Pahlawan Desa No. 132 Margaasih Cimahi 40533. Penelitian ini dilakukan pada kurun waktu kurang dari satu tahun, maka metode yang tepat digunakan untuk penelitian ini adalah cross sectional method.

Berdasarkan penjelasan dan bidang penelitian, maka jenis penelitian ini adalah penelitian deskriptif dan verifikatif, namun yang menjadi bahasan pada jurnal ini hanya bagian analisis verifikatif. Penelitian verifikatif dalam penelitian ini bertujuan untuk menguji kebenaran dari hipotesis yang dilaksanakan melalui pengumpulan data di lapangan guna memprediksi dan menjelaskan pengaruh lingkungan kerja terhadap employee engagement pada karyawan bagian produksi PT. Pola Manunggal Sejati Cimahi.

Populasi dalam penelitian ini adalah karyawan bagian produksi PT. Pola Manunggal Sejati Cimahi yang berjumlah 402 orang, yang kemudian dilakukan penarikan sampel terhadap populasi tersebut. Teknik penarikan sampel yang 
digunakan dalam penelitian ini adalah teknik simple random sampling, yaitu pengambilan anggota sampel dari populasi yang dilakukan secara acak tanpa memperhatikan strata yang ada dalam populasi tersebut (Sugiyono, 2017:63). Berdasarkan hasil perhitungan jumlah sampel dengan menggunakan rumus

\section{HASIL DAN PEMBAHASAN}

\begin{abstract}
Pengujian ini dilakukan untuk mengukur seberapa besar pengaruh lingkungan kerja terhadap employee engagement karyawan bagian produksi PT. Pola Manunggal Sejati Cimahi, maka akan dilakukan perhitungan dengan analisis regresi linier sederhana.
\end{abstract}

\section{A. Uji Asumsi Regresi Linier Sederhana}

Sebelum melakukan evaluasi terhadap model pengukuran dalam regresi linier sederhana mengenai pengaruh lingkungan kerja terhadap employee engagement pada karyawan bagian produksi PT. Pola Manunggal Sejati Cimahi, perlu dilakukan uji asumsi klasik regresi linier sederhana yang terdiri dari uji normalitas, uji linearitas, diagram pencar, dan uji titik terpencil. Berikut ini dipaparkan hasil uji asumsi klasik yang dilakukan dalam penelitian ini.

\section{Uji Normalitas}

Uji normalitas dilakukan untuk melihat apakah populasi berdistribusi normal atau tidak. data menyebar sekitar garis diagonal dan mengikuti arah diagonal. Maka regresi tersebut dapat disimpulkan populasi memenuhi asumsi berdistribusi normal. Selain itu untuk lebih memperkuat bukti bahwa data hasil penelitian berdistribusi normal atau tidak, maka peneliti melakukan pengujian normalitas menggunakan Kolmogorov-Smirnof Test.

Pada uji Kolmogorov Smirnov jika signifikansi di bawah 0,05 berarti terdapat perbedaan yang signifikan, dan jika signifikansi di atas 0,05 maka tidak terjadi perbedaan yang signifikan. Penerapan pada uji Kolmogorov Smirnov adalah bahwa jika
Slovin, maka diperoleh ukuran sampel secara keseluruhan sebanyak 81 orang sampel. Teknik analisis yang digunakan adalah analisis regresi linear sederhana dengan alat bantu program SPSS (Statistical Product for Service Solution) 25.0 for Windows.

signifikansi di bawah 0,05 berarti data yang akan diuji mempunyai perbedaan yang signifikan dengan data normal baku, berarti data tersebut tidak normal. Hasil tersebut menunjukkan perolehan nilai sebesar 0,200 lebih besar dari 0,05. Maka regresi tersebut dapat disimpulkan populasi memenuhi asumsi berdistribusi normal.

\section{Uji Linearitas}

Setelah data diketahui berdistribusi normal, maka selanjutnya perlu diketahui apakah kedua variabel tersebut benar benar memiliki hubungan linier. Untuk itu perlu dilakukan uji linearitas regresi variabel $\mathrm{X}$ atas variabel $Y$. Pengujian linearitas ini dimaksudkan untuk mengetahui kemungkinan adanya hubungan linear antara lingkungan kerja terhadap employee engagement.

Berdasarkan hasil uji linearitas diketahui $F_{\text {hitung }}$ sebesar 3,362 dengan signifikansi deviation from linearity sebesar $0,170>0,05$, artinya terdapat hubungan linier secara signifikan antara valiabel lingkungan kerja (X) dengan variabel employee engagement (Y). Dapat disimpulkan bahwa data yang dihasilkan memenuhi asumsi linearitas.

\section{Diagram Pencar}

Diagram pencar atau scatter plot digunakan untuk mengetahui dan menunjukan ada tidaknya hubungan antara variabel $\mathrm{X}$ dan variable $\mathrm{Y}$ melalui penggambaran nilai dari variabel-variabel tersebut.

Titik-titik pada diagram pencar diatas menyebar berbentuk pola dari kiri bawah menuju kanan atas. Dari diagram tersebut dapat diketahui arah $\mathrm{X}$ dan $\mathrm{Y}$ 
bersifat searah, artinya apabila $\mathrm{X}$ berubah semakin besar, maka $\mathrm{Y}$ pun berubah semakin besar, hal ini menunjukan adanya hubungan positif antara variabel $\mathrm{X}$ dan $\mathrm{Y}$.

\section{Uji Titik Terpencil}

Setelah diketahui model diagram pencar dan menunjukan pola garis lurus atau linear, langkah selanjutnya adalah memperhatikan titik-titik yang letaknya terpencil pada diagram pencar.

Selanjutnya untuk mengetahui apakah titik tersebut merupakan titik terpencil, maka dilakukan perhitungan dengan menggunakan rumus statistik. Dimana keriteria yang digunakan dalam uji ini yaitu:

$$
\begin{aligned}
t>t_{n-2}: & \text { Tolak } H_{o}, \text { artinya titik yang } \\
& \text { mencurigakan dianggap } \\
& \text { sebagai titik terpencil dan harus } \\
& \text { dikeluarkan dari analisis. } \\
t \leq t_{n-2}: & \text { Terima } H_{o}, \text { artinya titik yang } \\
& \text { mencurigakan tidak dianggap } \\
& \text { sebagai titik terpencil dan tidak } \\
& \text { perlu dikeluarkan dari analisis. }
\end{aligned}
$$

\section{B. Analisis Regresi Linier Sederhana}

Diperoleh persamaan regresi linier sederhana antara lingkungan kerja terhadap employee engagement, yaitu sebagai berikut:

$$
\mathrm{Y}=25,428+0,833 \mathrm{X}
$$

Berdasarkan persamaan regresi linier sederhana di atas, dapat di lihat angka-angka yang tertera pada persamaan regresi linier sederhana tersebut diambil dari tabel Unstandarized Coefficients (Janie, 2012:17).

Konstanta sebesar 25,428, menyatakan bahwa jika lingkungan kerja tidak diperbaiki atau tidak ditingkatkan $(\mathrm{X}=0)$ maka employee engagement bernilai 25,428 satu satuan nilai. Koefisien regresi 0,833 satu satuan nilai artinya setiap terjadi peningkatan lingkungan kerja akan meningkatkan employee engagement sebesar 0,833 satu satuan nilai dan sebaliknya jika terjadi penurunan employee engagement, lingkungan kerja akan menurunkan employee engagement sebesar
0,833 satu satuan nilai. Koefisien regresi bernilai positif, sehingga arah pengaruh variabel lingkungan kerja terhadap employee engagement adalah positif.

Besarnya nilai korelasi atau hubungan (R) yaitu sebesar 0,844. Dari output tersebut diperoleh koefisien determinasi (R Square) sebesar 0,712 yang berarti bahwa pengaruh variabel bebas (lingkungan kerja) terhadap variabel terikat (employee engagement) adalah sebesar $71,2 \%$.

\section{Koefisien Determinasi}

Untuk mengetahui hubungan antara lingkungan kerja dengan employee engagement dapat dilakukan dnegan menggunakan analisis koefisien korelasi pearson. Analisis koefisien korelasi ini bertujuan untuk menguji ada tidaknya korelasi atau hubungan dari lingkungan kerja employee engagement.

Hasil yang diperoleh menjelaskan bahwa korelasi antara lingkungan kerja dan employee engagement adalah sebesar 0,844 yang kemudian dapat di interpretasikan sebagai hubungan yang "kuat". Hasil ini selaras dengan output model summary yang dihasilkan melalui SPSS pada analisis regresi linier sederhana. Nilai signifikansi berada pada 0,000 yang berarti $<0,05$ maka dapat diketahui bahwa lingkungan kerja berkorelasi dengan employee engagement.

Selanjutnya untuk menafsirkan seberapa besar pengaruh lingkungan kerja terhadap employee engagement digunakan pedoman interpretasi koefisien penentu dalam tabel. Nilai koefisien penentu berada diantara $0-100 \%$. Jika nilai koefisien semakin mendekati $100 \%$ berarti semakin kuat pengaruh variabel independen terhadap variabel dependen. Sebaliknya apabila semakin mendekati $0 \%$ berarti semakin lemah pengaruh variabel independen terhadap variabel dependen.

Berdasarkan perhitungan, koefisien determinasi untuk lingkungan kerja (X) terhadap employee engagement (Y) adalah $71,2 \%$. Hasil ini selaras dengan output model summary yang dihasilkan melalui 
SPSS pada analisis regresi linier sederhana. Dengan kata lain, employee engagement dipengaruhi $71,2 \%$ oleh lingkungan kerja, sedangkan $28,8 \%$ dipengaruhi oleh factorfaktor lain. Nilai koefisien determinasi sebesar $71,2 \%$ kemudian dapat ditafsirkan bahwa pengaruh lingkungan kerja terhadap employee engagement berpengaruh "kuat".

\section{Pengujian Hipotesis}

1. Uji F

Uji $F$ atau uji keberartian regresi dilakukan untuk mengetahui apakah model regresi dalam penelitian ini sudah benar, maka dilakukan uji hipotesis. Dimana hipotesisnya adalah sebagai berikut:

$\mathrm{H}_{0}=$ regresi tidak berarti

$\mathrm{H}_{\mathrm{a}}=$ regresi berarti

Dengan syarat:

a. Taraf nyata yang digunakan $(\alpha)=5 \%$ atau 0,05 dengan derajat kebebasan df1 $=\mathrm{k}$ dan $\mathrm{df} 2=\mathrm{n}-\mathrm{k}$

b. Menentukan kriteria pengujian.

$\mathrm{H}_{0}$ diterima bila $\mathrm{F}_{\text {hitung }} \leq \mathrm{F}_{\text {tabel }}$ dan $\mathrm{H}_{0}$ ditolak bila $F_{\text {hitung }} \geq \mathrm{F}_{\text {tabel }}$

c. Menentukan nilai statistik F

Hasil yang diperoleh menunjukan nilai $F_{\text {hitung }}$ adalah 195,707. $F_{\text {tabel }}$ dapat dilihat pada tabel statistika dengan tingkat keyakinan 0,05 dengan df $1=1$ dan df $2=(n-$ k) dalam penelitian ini df 2 yang dihasilkan 81-1=80. Hasil $F_{\text {tabel }}$ sebesar 3,96.

Berdasarkan langkah-langkah pengujian di atas dengan tingkat keyakinan $\alpha 0,05(5 \%)$ diketahui, nilai signifikansinya 0,005 lebih kecil dari tingkat keyakinannya $(0,005<0,05), F_{\text {hitung }}$ lebih besar dari $\mathrm{F}_{\text {tabel }}$ yaitu 195,707 > 3,96, maka $\mathrm{H}_{\mathrm{o}}$ ditolak dan $\mathrm{H}_{\mathrm{a}}$ diterima. Hasil penelitian ini menunjukan bahwa regresi berarti, yaitu lingkungan kerja memiliki tingkat keberartian terhadap employee engagement sehingga penelitian ini bisa dilanjutkan menggunakan uji keberartian koefisien regresi.

\section{Uji f}

Untuk menguji keberartian koefesien regresi dilakukan melalui uji $\mathrm{t}$ dengan cara membandingkan antara thitung dengan ttabel dari koefisien regresi tiap variabel independen. Secara statistik, hipotesis yang akan diuji dalam rangka pengambilan keputusan penerimaan atau penolakan hipotesis dapat dirumuskan sebagai berikut :

Formulasi hipotesis.

Bila $t_{\text {hitung }} \geq \mathrm{t}_{\text {tabel}}$, maka $\mathrm{H}_{\mathrm{o}}$ ditolak dan $\mathrm{H}_{\mathrm{a}}$ diterima

Bila $t_{\text {hitung }} \leq \mathrm{t}_{\text {tabel }}$, maka $\mathrm{H}_{\mathrm{o}}$ diterima dan $\mathrm{H}_{\mathrm{a}}$ ditolak

Secara statistik, hipotesis yang akan diuji dalam rangka pengambilan keputusan penerimaan atau penolakan hipotesis dapat dirumuskan sebagai berikut.

Hipotesis:

$\mathrm{H}_{0}: \rho \leq 0$, artinya lingkungan kerja tidak berpengaruh terhadap employee engagement.

$\mathrm{Ha}: \quad \rho>0$, artinya lingkungan kerja berpengaruh terhadap employee engagement.

Hasil yang diperoleh menunjukan pengujian untuk uji $\mathrm{t}$ dengan bantuan program SPSS (Statistical Product and Service Solution) 25.0 for Windows. Uji t ini digunakan untuk mengetahui apakah variabel independen berpengaruh atau tidak terhadap variabel dependen. Dapat diketahui besarnya thitung melalui uji $t$ sebesar 13,990 untuk $\mathrm{X}_{1}$ sedangkan besarnya $t_{\text {tabel }}=1,66$ karena nilai $t_{\text {hitung }}>t_{\text {tabel }}$ yakni: $X=13,990>1,66$ maka dapat disimpulkan $\mathrm{H}_{0}$ ditolak dan $\mathrm{Ha}$ diterima.

Dari hasil uji t di atas disimpulkan bahwa hipotesis dalam penelitian ini yaitu $\mathrm{H}_{0}$ ditolak dan $\mathrm{Ha}$ diterima, sehingga terdapat pengaruh lingkungan kerja terhadap employee engagement pada karyawan bagian produksi PT. Pola Manunggal Sejati Cimahi. Berdasarkan nilai signifikansi yang diperoleh sebesar 0.000 yang berarti $<0.05$ dapat disimpulkan bahwa variabel lingkungan kerja (X) berpengaruh terhadap variabel employee engagement $(\mathrm{Y})$.

\section{KESIMPULAN DAN SARAN}

Kesimpulan dari penelitian ini adalah gambaran lingkungan kerja di PT. 
Pola Manunggal Sejati Cimahi berada pada kategori baik. Dimensi lingkungan kerja yang memiliki penilaian paling tinggi dalam mempengaruhi employee engagement adalah dimensi lingkungan kerja sosial, sedangkan dimensi yang memiliki penilaian paling rendah dalam mempengaruhi employee engagement adalah dimensi lingkungan kerja fisik. Sehingga dapat disimpulkan bahwa kondisi lingkungan kerja yang terjadi di PT. Pola Manunggal Sejati Cimahi hampir seluruhnya sudah baik.

Sementara itu gambaran employee engagement pada karyawan bagian produksi di PT. Pola Manunggal Sejati Cimahi berada pada kategori tinggi. Dimensi employee engagement yang memiliki penilaian paling tinggi adalah dimensi dedication (dedikasi), sedangkan dimensi yang memiliki penilaian paling rendah adalah dimensi absorption (penghayatan). Sehingga dapat disimpulkan bahwa tingkat employee engagement yang terjadi di PT. Pola Manunggal Sejati Cimahi hampir seluruhnya sudah tinggi.

Berdasarkan penelitian di atas, menyatakan bahwa lingkungan kerja mempunyai pengaruh terhadap employee engagement. Hal ini menunjukkan bahwa semakin baik kondisi lingkungan kerja yang ada di perusahaan, maka semakin baik pula tingkat employee engagement pada karyawan di perusahaan tersebut.

Penulis merekomendasikan supaya perusahaan terus memperbaiki dan meningkatkan lingkungan kerja yang dimiliki, dengan menjaga, memelihara, serta meningkatkan kondisi lingkungan kerja yang lebih baik agar terciptanya semangat dan motivasi dalam bekerja serta peningkatan kinerja yang akan berdampak positif terhadap tingkat employee engagement. Dengan semakin baik lingkungan kerja yang ada di tempat kerja, maka semakin baik pula employee engagement pada karyawannya. Sebagaimana menurut Anitha (2014), yang menegaskan bahwa employee engagement dalam suatu organisasi tergantung pada kondisi lingkungan kerja mereka. Semakin kondusif kondisi lingkungan kerja di suatu perusahaan yang ada, maka akan semakin tinggi pula tingkat employee engagement pada karyawan di perusahaan tersebut.

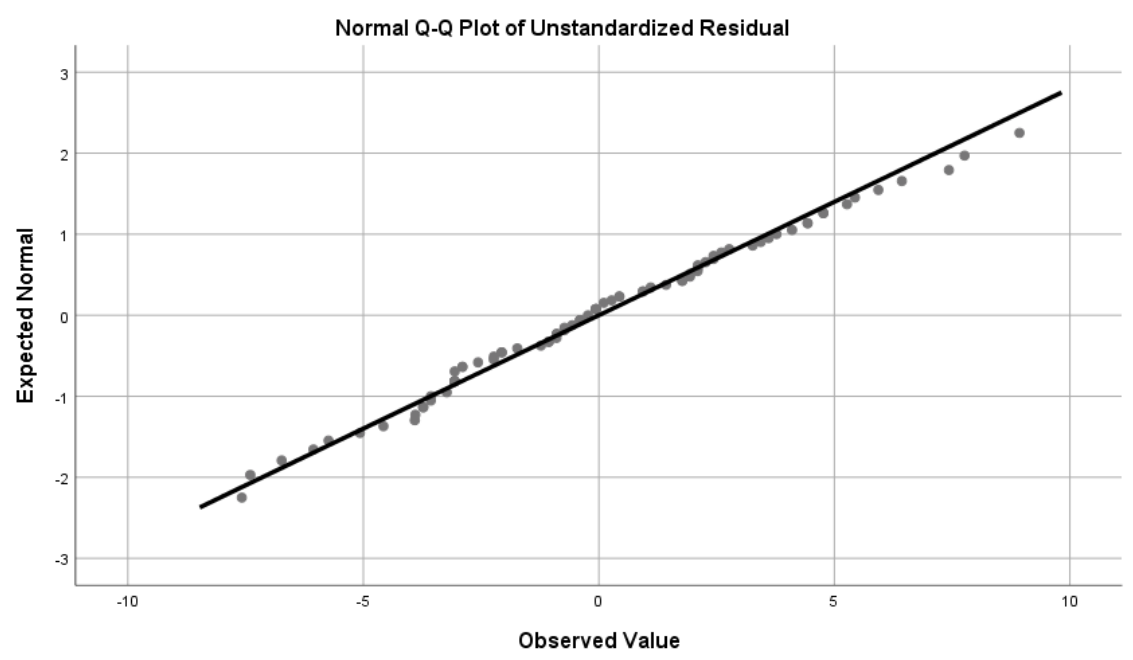

GAMBAR 2.

OUTPUT UJI NORMALITAS 
TABEL 4.

OUTPUT UJI KOLMOGOROV SMIRNOV

\begin{tabular}{|c|c|c|}
\hline \multicolumn{3}{|c|}{ One-Sample Kolmogorov-Smirnov Test } \\
\hline & & $\begin{array}{l}\text { Unstandardized } \\
\text { Residual }\end{array}$ \\
\hline \multicolumn{2}{|l|}{$\mathrm{N}$} & 81 \\
\hline \multirow{2}{*}{ Normal Parameters ${ }^{\mathrm{a}, \mathrm{b}}$} & Mean & .0000000 \\
\hline & Std. Deviation & 3.57330599 \\
\hline \multirow[t]{3}{*}{ Most Extreme Differences } & Absolute & .063 \\
\hline & Positive & .063 \\
\hline & Negative & -.051 \\
\hline \multicolumn{2}{|l|}{ Test Statistic } & .063 \\
\hline \multicolumn{2}{|l|}{\begin{tabular}{|l} 
Asym. Sig. (2-tailed) \\
\end{tabular}} & $200^{\mathrm{c}, \mathrm{d}}$ \\
\hline
\end{tabular}

a. Test distribution is Normal.

b. Calculated from data.

c. Lilliefors Significance Correction.

Sumber: Hasil Pengolahan Data 2019

TABEL 5.

OUTPUT UJI LINEARITAS

\begin{tabular}{|c|c|c|c|c|c|c|c|}
\hline \multicolumn{8}{|c|}{ ANOVA Table } \\
\hline & & & Sum of Squares & $\mathrm{df}$ & Mean Square & $\mathrm{F}$ & Sig. \\
\hline \multirow[t]{5}{*}{$E E *$ LK } & \multirow{3}{*}{$\begin{array}{l}\text { Between } \\
\text { Groups }\end{array}$} & (Combined) & 3074.586 & 21 & 146.409 & 18.094 & .000 \\
\hline & & Linearity & 2530.519 & 1 & 2530.519 & 312.728 & .000 \\
\hline & & $\begin{array}{l}\text { Deviation from } \\
\text { Linearity }\end{array}$ & 544.068 & 20 & 27.203 & 3.362 & .170 \\
\hline & \multicolumn{2}{|c|}{ Within Groups } & 477.414 & 59 & 8.092 & & \\
\hline & \multicolumn{2}{|l|}{ Total } & 3552.000 & 80 & & & \\
\hline
\end{tabular}

Sumber: Hasil Pengolahan Data 2019

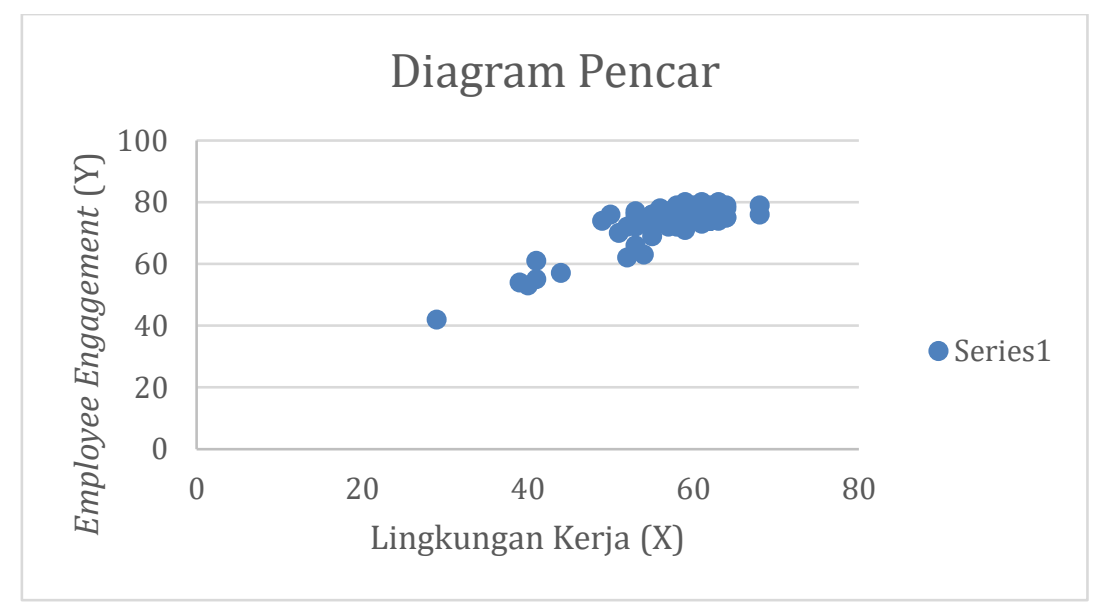

GAMBAR 3.

OUTPUT DIAGRAM PENCAR 


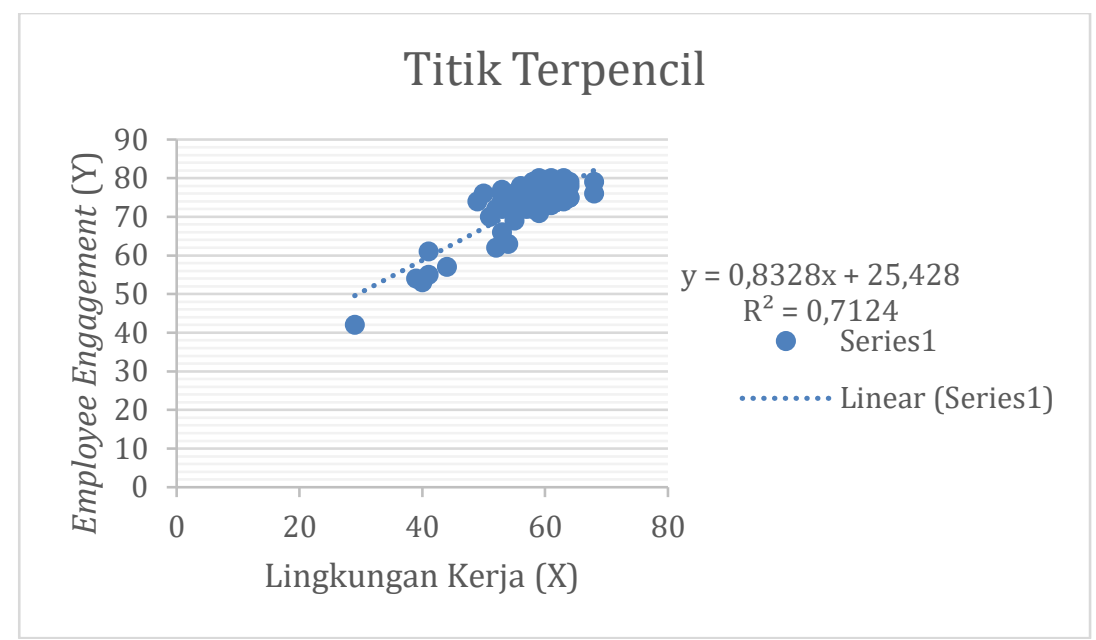

GAMBAR 4.

OUTPUT UJI TITIK TERPENCIL

TABEL 6. UJI TITIK TERPENCIL

\begin{tabular}{|c|c|c|c|c|c|c|}
\hline$\hat{\mathbf{Y}}$ & $\mathbf{X}$ & $\begin{array}{c}Y=0,8328 x+ \\
25,428\end{array}$ & $\begin{array}{c}S_{Y-\widehat{Y}} \\
(0,05-\hat{Y})\end{array}$ & $t=\frac{\text { thitung }-\widehat{Y}}{S_{Y-\widehat{Y}}}$ & $\begin{array}{c}t_{\text {tabel }} \\
(\mathbf{8 1 - 2})\end{array}$ & Keterangan \\
\hline 42 & 29 & $\begin{array}{c}0,8328.29+ \\
25,428=49,57\end{array}$ & $-41,95$ & $-0,18$ & 0,67 & $\begin{array}{c}\text { Bukan titik } \\
\text { terpencil }\end{array}$ \\
\hline 57 & 44 & $\begin{array}{c}0,8328.44+ \\
25,428=62,07\end{array}$ & $-56,5$ & $-0,089$ & 0,67 & $\begin{array}{c}\text { Bukan titik } \\
\text { terpencil }\end{array}$ \\
\hline
\end{tabular}

Sumber: Hasil Pengolahan Data 2019

TABEL 7.

OUTPUT MODEL REGRESI LINIER SEDERHANA LINGKUNGAN KERJA (X) TERHADAP EMPLOYEE ENGAGEMENT (Y)

\begin{tabular}{|c|c|c|c|c|c|c|}
\hline \multicolumn{7}{|c|}{ Coefficients $^{a}$} \\
\hline & \multicolumn{2}{|c|}{ Unstandardized C } & \multirow{2}{*}{$\begin{array}{c}\text { Standardized } \\
\text { Coefficients } \\
\text { Beta } \\
\end{array}$} & \multirow{3}{*}{$\begin{array}{l}t \\
7.359\end{array}$} & \multirow{3}{*}{$\frac{\text { Sig. }}{.000}$} \\
\hline & & & Std. Error & & & \\
\hline 1 & (Constant) & 25.428 & 3.455 & & & \\
\hline & Lingkungan Kerja & .833 & .060 & 844 & 13.990 & 00 \\
\hline
\end{tabular}

a. Dependent Variable: Employee Engagement

Sumber: Hasil Pengolahan Data 2019

TABEL 8.

OUTPUT MODEL SUMMARY

\begin{tabular}{|l|c|r|r|r|}
\hline \multicolumn{5}{|c|}{ Model Summary } \\
\hline Model & R & R Square & $\begin{array}{c}\text { Adjusted R } \\
\text { Square }\end{array}$ & $\begin{array}{c}\text { Std. Error of the } \\
\text { Estimate }\end{array}$ \\
\hline 1 & $.844^{\mathrm{a}}$ & .712 & .709 & 3.59585 \\
\hline
\end{tabular}

a. Predictors: (Constant), Lingkungan Kerja

b. Dependent Variable: Employee Engagement

Sumber: Hasil Pengolahan Data 2019 
TABEL 9.

OUTPUT KORELASI PEARSON

\begin{tabular}{|c|c|c|c|}
\hline \multicolumn{4}{|c|}{ Correlations } \\
\hline & & LK & EE \\
\hline \multirow[t]{3}{*}{ Lingkungan Kerja } & Pearson Correlation & 1 & $.844^{* *}$ \\
\hline & Sig. (2-tailed) & & .000 \\
\hline & $\mathrm{N}$ & 81 & 81 \\
\hline \multirow{3}{*}{$\begin{array}{l}\text { Employee } \\
\text { Engagement }\end{array}$} & Pearson Correlation & $.844^{* *}$ & 1 \\
\hline & Sig. (2-tailed) & .000 & \\
\hline & $\mathrm{N}$ & 81 & 81 \\
\hline
\end{tabular}

**. Correlation is significant at the 0.01 level (2-tailed)

Sumber: Hasil Pengolahan Data 2019

TABEL 10.

\section{OUTPUT NILAI SIGNIFIKANSI UJI F}

\begin{tabular}{|l|l|r|r|r|r|r|}
\hline \multicolumn{7}{|c|}{ ANOVA $^{\mathrm{a}}$} \\
\hline \multicolumn{2}{|l|}{ Model } & Sum of Squares & df & Mean Square & F & \multicolumn{1}{c|}{ Sig. } \\
\hline \multirow{3}{*}{1} & Regression & 2530.519 & 1 & 2530.519 & 195.707 & $.000^{\mathrm{b}}$ \\
\cline { 2 - 8 } & Residual & 1021.481 & 79 & 12.930 & & \\
\cline { 2 - 8 } & Total & 3552.000 & 80 & & & \\
\hline
\end{tabular}

a. Dependent Variable: Employee Engagement

b. Predictors: (Constant), Lingkungan Kerja

Sumber: Hasil Pengolahan Data 2019

TABEL 11.

OUTPUT NILAI SIGNIFIKANSI UJI t

\begin{tabular}{|c|c|c|c|c|c|c|}
\hline \multicolumn{7}{|c|}{ Coefficients $^{a}$} \\
\hline \multirow{2}{*}{\multicolumn{2}{|c|}{ Model }} & \multicolumn{2}{|c|}{ Unstandardized Coefficients } & \multirow{2}{*}{$\begin{array}{c}\text { Standardized } \\
\text { Coefficients } \\
\text { Beta }\end{array}$} & \multirow[b]{2}{*}{$\mathrm{t}$} & \multirow[b]{2}{*}{ Sig. } \\
\hline & & $\mathrm{B}$ & Std. Error & & & \\
\hline 1 & (Constant) & 25.428 & 3.455 & & 7.359 & .000 \\
\hline & Lingkungan Kerja & .833 & .060 & .844 & 13.990 & .000 \\
\hline
\end{tabular}

a. Dependent Variable: Employee Engagement

Sumber: Hasil Pengolahan Data 2019

\section{DAFTAR PUSTAKA}

Al-Tit, A., \& Hunitie, M. (2015). The Mediating Effect of Employee Engagement between Its Antecedents and Consequences. Journal of Management Research, 7(5), 47. https://doi.org/10.5296/jmr.v7i5.8048

Anitha. (2014). Determinants of employee engagement and their impact on employee performance. International Journal of Productivity and Performance Management, 63(3), 308-323.

https://doi.org/10.1108/IJPPM-012013-0008

Hani, T. H. (2014). Manajemen Personalia dan Sumber Daya Manusia. https://doi.org/10.1007/s00421-0112167-x.

J. Josephine, V. S. (2013). Employee Engagement, An Approach to Organisational Excellence. 2(5), 111117.

Janie, D. N. A. (2012). Statistik Deskriptif \& Regresi Linier Berganda dengan SPSS. Semarang: Semarang University Press.

Johari, J., Adnan, Z., Tan, F. Y., Yahya, K. K., \& Isa, S. N. (2013). Fostering employee engagement through human resource practices: A case of manufacturing firms in Malaysia. Jurnal Pengurusan, 38, 15-26. 
Koti, K., \& Road, M. (2015). ISSN : 23211784 International Journal in Management and Social Science ( Impact Factor- 3.25 ) International Journal in Management and Social Science ISSN : 2321-1784 International Journal in Management and Social Science ( Impact Factor- 3 . 25 ) Inte. International Journal in Management and Social Science, 03(03), 249-258. https://doi.org/23211784

Lockwood, N. R. (2007). Leveraging Employee Engagement for Competitive Advantage. Research Quarterly, 52(3), 1-12. https://doi.org/10.1109/HICSS.2007.3 24

McBain, R. (2007). The practice of engagement: Research into current employee engagement practice. 6(6), 16-19.

Michael Armstrong \& Stephen Taylor. (2017). Handbook of Human Resource Management Practice. London: Kogan Page.

Mishra, S. (2016). The Predictors of Employee Engagement: A Study in a Ferro Alloys Company of India. https://doi.org/10.1177/09721509166 60429

Mohd, I. H., Mohd Shah, M., \& Zailan, N. S. Z. (2016). How Work Environment affects the Employee Engagement in a Telecommunication Company. 418426.

https://doi.org/10.15405/epsbs.2016.1 1.02 .37

Nazir, O., \& Islam, J. U. (2017). Enhancing organizational commitment and employee performance through employee engagement. South Asian Journal of Business Studies, 6(1), 98114. https://doi.org/10.1108/SAJBS04-2016-0036

Pan, S., \& Degree, L. A. (2015). ISSN : 2321-1784 International Journal in Management and Social Science ( Impact Factor- 3 . 25 ) International Journal in Management and Social Science ISSN : 2321-1784 International Journal in Management and Social Science ( Impact Factor- 3 .25 ) Inte. International Journal in Management and Social Science, 03(02), 718-725. https://doi.org/23211784

Saks, A. M. (2006). Antecedents and consequences of employee engagement. Journal of Managerial Psychology, 21(7), 600-619. https://doi.org/10.1108/02683940610 690169

Sedarmayanti. (2014). Sumber Daya Manusia dan Produktivitas Kerja. Jakarta: Mandar Maju.

Sugiyono. (2017). Metode Penelitian Kuantitatif, Kualitatif, dan $R \& D$. Bandung: Alfabeta.

Sujeewa, W. (2011). Relationship between Human Resource Management NonManagerial Employee Intention to Turnover in Garment Industry in Sri Lanka. 535-539.

Sumadhinata, Y. E., \& Murtisari, M. (2017). Pengaruh Pengembangan Karir Terhadap Employee Engagement Pada Karyawan Darat PT. ASDP. Conference on Management and Behavioral Studies, 165-172. 